\title{
Inovasi Klaim Elektronik Jaminan Hari Tua di BPJS Ketenagakerjaan Kantor Cabang Makassar
}

\author{
Innovation of Old Age Electronic Benefits Claim at the Makassar Branch \\ Employment Office BPJS
}

\author{
Muhammad Nur Alim, Muh. Tahir Haning², Syahribulan ${ }^{3}$ \\ 1Departemen Administrasi Publik, Universitas Hasanuddin, Indonesia. E-mail : alim.unhas@gmail.com \\ 2Departemen Administrasi Publik, Universitas Hasanuddin, Indonesia. E-mail : thahir.haning@gmail.com \\ ${ }^{3}$ Departemen Administrasi Publik, Universitas Hasanuddin, Indonesia. E-mail : \\ syahribulansunusi@yahoo.com
}

\section{ARTICLE INFO}

Keywords: Innovation, Service, electronic Claim

Kata kunci : Inovasi, pelayanan, klaim elektronik

How to cite: Alim, M. N., Haning, M. T., E Syahribulan. (2020). Inovasi Klaim Elektronik Jaminan Hari Tua di BPJS

Ketenagakerjaan Kantor Cabang Makassar. JAKPP (Jurnal Analisis Kebijakan dan Pelayanan Publik), 6(1), 1-14.

\section{ABSTRACT}

Electronic Claim as a Services Innovation on Old Age Benefits at BPJS Ketenagakerjaan Makassar Branch Office (supervised by Muh. Thahir Haning and Syahribulan). This study aims to analyze the implementation of electronic claims as service innovation at BPJS Ketenagakerjaan Makassar Branch Office on Old Age Benefits by using a model in measuring innovation according to the UN Public Service Awards (2017) criteria with indicators ; Leadership and capacities for innovative government, Transparent, accountable and participatory institutions, Overcoming challenges through technology, Policy coherence and integration. This study uses qualitative data analysis techniques by thorough interpretation and verification of every information through interviews, secondary data collection and literature study, and other sources. Information was obtained from BPJS Ketenagakerjaan, claim participants, government and private sectors partners. The results of this study indicate that the application of electronic claims as service innovation at BPJS Ketenagakerjaan Makassar Branch Office implemented: 1) in accordance with Leadership and capacities for innovative government criteria due to collaboration with government, private sectors and non-governmental institutions and efforts to develop electronic claim innovation; 2) in according to transparent, Transparent, accountable and participatory institutions criteria due to creating transparency on deposit management, information disclosure and controlling to keep the process running in accordance with regulations. 3) less in optimalizing of overcoming challenge through technology because electronic claim still requires employee involvement on verification process; and 4) less in maximalizing Policy coherence and integration because it is still constrained by additional employees which is authority of central office. The results of this study are expected to be used as study reference for policy makers in public sector, especially for BPJS Ketenagakerjaan Makassar Branch Office in order to further enhance the implementation of electronic claim innovation that prioritize the needs and community interests. 


\begin{abstract}
Abstrak
Inovasi Klaim Elektronik pada Jaminan Hari Tua di BPJS Ketenagakerjaan Kantor Cabang Makassar (dibimbing oleh Muh. Thahir Haning dan Syahribulan). Penelitian ini bertujuan menganalisis implementasi inovasi layanan klaim elektronik di BPJS Ketenagakerjaan Kantor Cabang Makassar pada Jaminan Hari Tua dengan menggunakan model pengukuran kriteria inovasi menurut UN Public Service Awards (2017) dengan indikator kepemimpinan dan kapasitas pemerintah yang inovatif; lembaga yang transparan, akuntabel dan partisipatif; mengatasi masalah melalui teknologi; serta kebijakan yang koheren dan terintegrasi. Penelitian ini menggunakan teknik analisis data kualitatif melalui interpretasi dan verifikasi cermat terhadap setiap informasi melalui wawancara, penghimpunan data sekunder maupun literatur, dan sumber lainnya. Informasi diperoleh dari pihak BPJS Ketenagakerjaan, peserta klaim, mitra pemerintah dan swasta. Hasil penelitian ini menunjukkan bahwa penerapan inovasi layanan klaim elektronik di BPJS Ketenagakerjaan Kantor Cabang Makassar dilaksanakan: 1) sesuai dengan kriteria kepemimpinan dan kapasitas pemerintah yang inovatif karena adanya kolaborasi dengan pihak pemerintah, swasta dan lembaga non pemerintah serta adanya upaya mengembangkan inovasi klaim elektronik; 2) sesuai dengan kriteria lembaga yang transparan, akuntabel dan partisipatif karena terciptanya transparansi terhadap pengelolaan dana, keterbukaan informasi dan pengawasan untuk menjaga proses berjalan sesuai dengan aturan yang berlaku. 3) kurang maksimal dalam mengatasi masalah melalui teknologi karena klaim elektronik masih membutuhkan keterlibatan pegawai dalam proses verifikasi; dan 4) kurang maksimal dalam kebijakan yang koheren dan terintegrasi karena masih terkendala dengan penambahan pegawai yang merupakan kebijakan di kantor pusat. Hasil penelitian ini diharapkan dapat dijadikan bahan kajian bagi pengambil kebijakan di sektor publik, khususnya BPJS Ketenagakerjaan Kantor Cabang Makassar agar lebih meningkatkan implementasi inovasi klaim elektronik yang mengutamakan kebutuhan dan kepentingan masyarakat.
\end{abstract}

\title{
Pendahuluan
}

Inovasi pada dasarnya adalah sebuah ide atau gagasan baru yang merupakan hasil dari pengembangan pengetahuan atau keterampilan yang dimiliki. Organisasi pelayanan publik diwajibkan memberikan pelayanan yang terbaik bagi masyarakat, oleh karenanya organisasi publik dituntut untuk terus melakukan inovasi agar dapat memenuhi harapan masyarakat.

Salah satu lembaga publik yang terus melakukan perbaikan layanan melalui inovasi yakni BPJS Ketenagakerjaan. Hal ini dilakukan untuk mengantisipasi semakin meluasnya sekop pelayanan BPJS Ketenagakerjaan yang berimplikasi pada meningkatnya klaim masyarakat dimasa yang akan datang. Sejak revisi Permenaker No 46/2015 tentang jaminan Hati Tua (JHT) dalam revisi tersebut pemerintah menjamin pekerja yang berhenti bekerja dapat mencairkan uangnya melalui Badan Penyelenggara Jaminan Sosial (BPJS) Ketenagakerjaan yang dulunya harus memenuhi kepesertaan atau menunggu 10 tahun terlebih dahulu. Kini tidak perlu menunggu masa kepesertaan 10 tahun, hanya perlu menunggu satu bulan setelah 
berhenti bekerja dari perusahaannya akibatnya klaim tenaga kerja meningkat secara drastis.

Menurut data BPJS Ketenagakerjaan Kantor Cabang Makassar setiap harinya melayani total rata-rata sebanyak 150-200 antrean yang terdiri dari antrean klaim dan antrean pelayanan perusahaan. Pada hari tertentu antrean bisa mencapai 300 antrean sehingga pelayanan harus dibatasi terkhusus pada klaim Jaminan Hari Tua maksimal 100 per hari. Hal ini menimbulkan lambatnya pelayanan sehingga masyarakat harus menunggu kurang lebih 2 jam lebih awal dari waktu seharusnya.

Melihat timbulnya permasalahan ini, maka pimpinan BPJS Ketenagakerjaan Kantor Cabang Makassar melakukan inovasi dalam pelayanan klaimnya, terkhusus klaim Jaminan Hari Tua (JHT) sejak tahun 2016. Untuk mengurangi muatan antrean yang begitu banyak, BPJS Ketenagakerjaan Kantor Cabang Makassar menerapkan sistem antrean dan verifikasi berkas pelayanan klaim berbasis online. Inovasi ini dinamakan Electronic Klaim atau disebut dengan klaim elektronik.

Setahun berjalan setelah diberlakukannya Klaim elektronik pada tahun 2016, memberikan solusi bagi BPJS Ketenagakerjaan Kantor Cabang Makassar dalam mengurai antrean serta melakukan verifikasi peserta klaim lebih awal. Hal ini pun memudahkan bagi calon peserta klaim dalam mendapatkan layanan dan kepastian layanan. Hal ini memberikan solusi bagi beberapa permasalahan yang dihadapi sebelumnya.

Tujuan diberlakuakannya klaim elektronik diharapkan agar semakin banyak masyarakat yang mengakses layanan tersebut, namun setahun berjalan diterapkannya, walaupun pengguna layanannya sudah meningkat namun masih banyak juga masyarakat yang belum menggunakan kanal layanan ini. Masih banyak masyarakat yang lebih memilih untuk melakukan antrean secara manual padahal layanan Klaim elektronik lebih memberikan kemudahan dan kepastian.

Dampak positif yang ditimbulkan dari inovasi ini sangat baik, namun kendalakendala yang masih ditemukan dalam penyelenggaraannya, oleh karenanya dilakukan penelitian terkait bagaimana inovasi klaim elektronik di BPJS Ketenagakerjaan Kantor Cabang Makassar. Penelitian ini bertujuan untuk Menganalisis dan mendeskripsikan Inovasi klaim elektronik di BPJS Ketenagakerjaan Kantor Cabang Makassar dengan menggunakan model pengkuran kriteria inovasi menurut UN Public Service Awards (2017).

\section{Kajian Literatur}

Secara etimologi, inovasi berasal dari kata latin In dan Novare yang bermakna membuat sesuatu yang baru, untuk mengubah (Bessant, 2009). Menurut kamus Bahasa Inggris Encarta Word English Dictionary, inovasi memiliki beberapa terminologi yang dapat digunakan untuk menjelaskan kata tersebut dalam bahasa Indonesia (a) innovate (verb) sebagai kata kerja, artinya memperkenalkan cara baru untuk melakukan sesuatu atau sebuah alat baru; (b) innovation (n) sebagai kata benda, memiliki arti sebuah kegiatan atau sebuah 
proses penciptaan atau memperkenalkan sesuatu yang baru diciptakan atau cara baru dalam melakukan sesuatu; (c) innovative (adj) sebagai kata sifat, artinya baru dan orisinil atau sebuah pendekatan baru dan orisinil (Microsoft, Encarta, Word English Dictionary, 1999).

Borins (2001) menyatakan bahwa dalam literatur inovasi terdapat perbedaan antara temuan (invention), kreasi ide baru, dan inovasi. Dalam literatur manajemen juga dikemukakan sejumlah definisi inovasi dimana secara luas berada dalam tema-tema perubahan proses atau teknologi yang menciptakan nilai bagi pelanggan atau organisasi. Inovasi yang berbeda tersebut semata-mata lebih kepada perubahan.

Menurut Hidayaningrat yang dikutip oleh Suwondo (2001), definisi pelayanan publik adalah suatu hal sebagai aktivitas yang dilakukan untuk memberikan jasa-jasa dan kemudahan bagi masyarakat untuk memegang teguh syarat-syarat efisiensi, efektivitas, dan penghematan. Pendapat ini didukung oleh Siagian (1992) yang mengemukakan bahwa pelayanan publik adalah aktivitas yang dilakukan untuk memberikan jasa-jasa dan kemudahan kepada masyarakat dengan mempertimbangkan aspek-aspek sebagai berikut: (a) Pelayanan publik berhubungan dengan kegiatan memberikan pelayanan kepada masyarakat sesuai dengan haknya, (b) Pelayanan yang diberikan berupa barang dan jasa yang vital, dan (c) Adanya prinsip-prinsip efisiensi, efektivitas dan penghematan dalam memberikan pelayanan kepada masyarakat.

Inovasi adalah fitur layanan publik yang terus-menerus, didorong oleh kebutuhan untuk tetap relevan dan responsif terhadap kebutuhan orang. Adapun Model Inovasi Pelayanan yang diperkenalkan oleh United Nation Public Service Award tahun 2017 diperlukan empat dimensi yaitu; (1).Kepemimpinan dan Kapasitas Pemerintah yang Inovatif. Kepemimpinan yang kolaboratif, etis, dan visioner adalah faktor kritis utama dalam mendorong inovasi dalam pelayanan publik. (2). Lembaga Transparan, Akuntabel dan Partisipatif. Lembaga dan proses yang transparan, akuntabel dan partisipatif merupakan faktor penting dalam mendorong inovasi dalam pelayanan publik (3). Mengatasi tantangan melalui teknologi. Kerangka kebijakan yang tepat dan kepemimpinan visioner, bagaimanapun, diperlukan untuk memastikan penggunaan teknologi yang tepat. Teknologi dapat menjadi pendorong inovasi yang kuat dalam pelayanan publik. (4). Koherensi Kebijakan yang Terintegrasi. Koherensi dan integrasi kebijakan hanya dapat terjadi jika komunikasi dan interaksi dan dukungan di antara aktoraktor yang berbeda dalam sektor publik dan dengan aktor non-pemerintah.

Tabel 2 : Indikator Inovasi Sektor Publik dalam UNPSA (2017).

\begin{tabular}{|c|l|l|ll|}
\hline No & \multicolumn{1}{|c|}{ Indikator } & \multicolumn{1}{|c|}{ Definisi/Penjelasan } & Sub Indukator \\
\hline 1 & $\begin{array}{l}\text { Kepemimpinan } \\
\text { dan Kapasitas } \\
\begin{array}{l}\text { Pemerintah yang } \\
\text { Inovatif }\end{array}\end{array}$ & $\begin{array}{l}\text { Pemerintah yang memiliki pengetahuan, } \\
\text { keterampilan, dan perilaku layaknya sebagai } \\
\text { pelayan publik. Pemerintah yang sadar akan } \\
\text { tujuan, mengembangkan kapasitas, pola pikir } \\
\text { kolaboratif dan konsultatif, serta kapasitas dan }\end{array}$ & $\begin{array}{l}\text { 1. Kepemimpinan yang } \\
\text { visioner } \\
\text { Keterampilan dan } \\
\text { kapasitas untuk } \\
\text { berinovasi }\end{array}$ \\
\hline
\end{tabular}




\begin{tabular}{|c|c|c|c|}
\hline & & $\begin{array}{l}\text { motivasi untuk selalu berinovasi dan mencoba } \\
\text { pendekatan baru. }\end{array}$ & $\begin{array}{l}\text { 3. Kepemimpinan yang } \\
\text { kolaboratif dan } \\
\text { konsultatif }\end{array}$ \\
\hline 2 & $\begin{array}{l}\text { Lembaga } \\
\text { Transparan, } \\
\text { Akuntabel dan } \\
\text { Partisipatif }\end{array}$ & $\begin{array}{l}\text { Lembaga dan proses yang transparan, akuntabel } \\
\text { dan partisipatif merupakan faktor penting dalam } \\
\text { mendorong inovasi dalam pelayanan publik. } \\
\text { Sejumlah bahan utama diperlukan untuk } \\
\text { membuat lembaga lebih transparan, termasuk: } \\
\text { memantau pekerjaan pemerintah dan } \\
\text { memberantas korupsi melalui partisipasi publik; } \\
\text { menghilangkan ketidaksetaraan dalam layanan } \\
\text { publik dan menyiapkan kerangka kerja regulasi } \\
\text { yang efisien untuk meningkatkan transparansi di } \\
\text { lembaga-lembaga pemerintah. }\end{array}$ & $\begin{array}{l}\text { 1. Proses organisasi yang } \\
\text { transparan } \\
\text { 2. Lembaga publik yang } \\
\text { akuntabel } \\
\text { 3. Kreativitas dalam } \\
\text { mencari saran \& } \\
\text { umpan balik dari } \\
\text { masyarakat }\end{array}$ \\
\hline 3 & $\begin{array}{l}\text { Mengatasi } \\
\text { Maslah dengann } \\
\text { Teknologi }\end{array}$ & $\begin{array}{l}\text { Kerangka kebijakan yang tepat dan } \\
\text { kepemimpinan visioner diperlukan untuk } \\
\text { memastikan penggunaan teknologi yang tepat. } \\
\text { Teknologi dapat menjadi pendorong inovasi yang } \\
\text { kuat dalam pelayanan publik. Menggabungkan } \\
\text { penggunaan teknologi dengan kebijakan pemuda, } \\
\text { sementara melakukan pengembangan kapasitas } \\
\text { dan pengembangan keterampilan secara } \\
\text { bersamaan, dapat menjadi sarana yang efektif } \\
\text { untuk mempromosikan inovasi. Penggunaan data } \\
\text { dan teknologi dapat memainkan peran penting } \\
\text { dalam memerangi korupsi. }\end{array}$ & 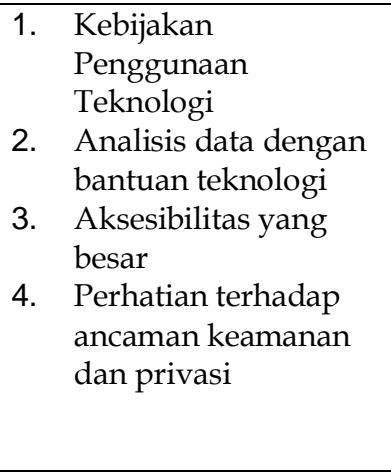 \\
\hline 4 & $\begin{array}{l}\text { Koherensi } \\
\text { Kebijakan yang } \\
\text { Terintegrasi }\end{array}$ & $\begin{array}{l}\text { Koherensi dan integrasi kebijakan hanya dapat } \\
\text { terjadi jika komunikasi dan interaksi di antara } \\
\text { aktor-aktor yang berbeda dalam sektor publik dan } \\
\text { dengan dukungan aktor non-pemerintah. }\end{array}$ & $\begin{array}{l}\text { 1. Koherensi kebijakan } \\
\text { 2. Dukungan dari } \\
\text { seluruh aktor publik }\end{array}$ \\
\hline
\end{tabular}

E-Government sering dideskripsikan secara beragam oleh masing-masingmasing individu atau institusi. Dalam cakupan negara, pemahaman mengenai konsep e-government di suatu negara tidak dapat dipisahkan dengan kondisi internal dari negara yang bersangkutan. World Bank mendefinisikan e-government yang mana dapat berarti bahwa e-government mengacu pada pemanfaatan TIK oleh institusi pemerintah, seperti Wide Area Network, Internet, Mobile Computing, yang selanjutnya dapat mendukung transformasi hubungan dengan warga negara, pelaku bisnis, dan institusi pemerintah lainnya.

Klaim elektronik adalah layanan yang diberikan oleh BPJS Ketenagakerjaan yang ditujukan kepada masyarakat untuk melakukan pengajuan klaim menggunakan layanan elektronik atau online. Klaim elektronik ini merupakan salah satu layanan electronic service yang dimiliki oleh BPJS Ketenagakerjaan. Fasilitas ini mulai diberlakukan di BPJS Ketenagakerjaan Kantor Cabang Makassar pada tahun 2016. Layanan ini bertujuan untuk mempermudah masyarakat dalam melakukan pengajuan klaim, terkhusus pada klaim Jaminan Hari Tua (JHT) yang merupakan klaim terbanyak di BPJS Ketenagakerjaan Kantor Cabang Makassar. Layanan ini diluncurkan agar prosedur pelayanan klaim dengan cara manual bisa dipermudah dengan menggunakan bantuan teknologi informasi dan telekomunikasi. 
Adapun penelitian terdahulu yang pernah dilakukan Eko Prasojo dan Teguh Kurniawan (2006), melakukan kajian inovasi pro masyarakat miskin melalui program bebas iuran sekolah sebagai bentuk inovasi urusan pendidikan di Kabupaten Jembrana. Penelitiannya berjudul: Bebas Iuran Sekolah dan Jaminan Kesehatan Jembrana: Inovasi Pro Masyarakat Miskin di Kabupaten Jembrana. Penelitian ini menggunakan metode kualitatif dengan strategi wawancara mendalam, FGD dan kajian dokumentasi. Konsep yang digunakan meliputi inovasi program.

\section{Metode Penelitian}

Penelitian ini menggunakan pendekatan kualitatif dengan jenis penelitian studi kasus pada layanan klaim elektronik di BPJS Ketenagakerjaan Kantor Cabang Makassar. Adapun informan ditentukan secara Purposive Sampling yaitu Kepala Kantor, Kepala Bidang Pelayanan, Staf Bidang Pelayanan, mitra pemerintah dan swasta serta masyarakat yang melakukan klaim yang dianggap representative untuk memberikan informasi. Teknik pengumpulan data dilakukan dengan wawancara mendalam, observasi dan studi data sekunder dari bidang kepesertaan dan bidang pelayanan BPJS Ketenagakerjaan Kantor Cabang Makassar. Data kemudian dianalisis dengan reduksi data, penyajian data, dan penarikan kesimpuan.

\section{Hasil Penelitian dan Pembahasan}

Inovasi layanan publik di berbagai instansi pemerintah menjadi hal yang sangat penting dalam meningkatkan kualitas layanannya, tidak terkecuali bagi BPJS Ketenagakerjaan Kantor Cabang Makassar. Penelitian ini mencoba membuktikan bahwa inovasi layanan publik klaim elektronik yang diterapkan oleh BPJS Ketenagakerjaan Kantor Cabang Makassar telah memenuhi kriteria inovasi lembaga pelayanan publik sesuai yang ditetapkan pada United Nations Public Service Award (2017). Adapun kriterianya meliputi kepemimpinan dan kapasitas pemerintah yang inovatif; lembaga yang transparan, akuntabel dan partisipatif; mengatasi masalah dengan teknologi; dan kebijakan yang koheren dan terintegrasi.

\section{Kepemimpinan dan Kapasitas Pemerintah yang Inovatif}

Hasil penelitian menunjukkan bahwa sebagai penentu kebijakan, pemimpin di BPJS Ketenagakerjaan Kantor Cabang Makassar memiliki pengetahuan, keterampilan dan perilaku layaknya pelayan masyarakat. Pimpinan sadar terhadap visi dan misi lembaga sehingga pola pikir yang dimiliki bersifat kolaboratif dan konsultatif yang mengarah pada motivasi untuk berinovasi dalam setiap aktivitas pelayanan publik yang dijalankan.

1. Kepemimpinan yang Visoner

Hasil penelitian menunjukkan bahwa Kepala BPJS Ketenagakerjaan Kantor Cabang Makassar melakukan upaya untuk mengarahkan bawahannya dalam hal 
pencapaian tujuan organisasi yang diharapkan. Kepala Cabang mengakui bahwa dalam menjalankan kepemimpinannya, berfokus pada visi organisasi. Penerapan klaim elektronik merupakan salah satu bentuk komitmen tataran pimpinan dalam mewujudkan visi lembaga, yakni unggul dalam operasional dan pelayanan, dalam hal ini melalui layanan klaim berbasis online. Menurutnya, pelaksanaan inovasi klaim elektronik akan terus ditingkatkan untuk menjawab berbagai permasalahan agar dapat menjadi suatu inovasi yang berkelanjutan atau sustainable.

\section{Keterampilan dan Kapasitas untuk Berinovasi}

Hasil penelitian menunjukkan bahwa BPJS Ketenagakerjaan memiliki beragam jenis inovasi sebagai wujud organisasi pelayanan publik yang terampil dan berkapasitas. Pemberlakuan program inovasi individu dan inovasi unit yang wajib dilaksanakan seluruh karyawan menjadi bukti bahwa BPJS Ketenagakerjaan memiliki strategi untuk meningkatkan kualitas layanannya terkhusus pada klaim elektronik. Hal tersebut memotivasi karyawan untuk menghadirkan ide baru yang akan digunakan oleh manajemen. Selain itu ada usaha dalam mengembangkan integrasi layanan klaim elektronik dengan perusahaan agar bisa mempercepat pelayanan.

\section{Kepimpinan yang Kolaboratif dan Konsultatif}

Hasil penelitian menunjukkan bahwa dalam penerapan inovasi layanan klaim elektronik, BPJS Ketenagakerjaan Kantor Cabang Makassar bekerja sama dengan pihak-pihak yang memiliki kepentingan yang sama dalam melayani masyarakat dan menguntungkan satu sama lain dalam mencapai tujuan pelayanan. Adapun pihak yang berkolaborasi dengan BPJS Ketenagakerjaan khususnya dalam pelaksanaan layanan klaim elektronik antara lain Pemerintah Provinsi Sulawesi Selatan, pihak swasta dan lembaga non pemerintah.

Bentuk kerja sama yang dilakukan oleh BPJS Ketenagakerjaan dan pihakpihak tersebut beragam, mulai dari pemberian fasilitas untuk melakukan sosialisasi regulasi jaminan sosial ketenagakerjaan, penyediaan data karyawan yang terintegrasi, pengawasan kepatuhan pemberi kerja, informasi pelayanan klaim, hingga pelaporan kecelakaan kerja.

\section{Lembaga yang Transparan, Akuntable dan Partisipatif}

Hasil penelitian menunjukkan bahwa BPJS Ketenagakerjaan Kantor Cabang Makassar telah menerapkan proses yang transparan, akuntabel, dan partisipatif dalam aktivitas pelayanan publik, termasuk penerapan klaim elektronik. Ketiga aspek tersebut dinilai sebagai faktor pendorong keberlangsungan suatu inovasi. Secara praktis, klaim elektronik telah menerapkan kriteria proses yang meliputi penyajian data kepesertaan yang akurat, penerbitan laporan pertanggungjawaban secara berkala, dan penerimaan suara publik berupa kritik dan saran melalui berbagai media. 


\section{Proses Organisasi yang Transparan}

Hasil penelitian menunjukkan bahwa BPJS Ketenagakerjaan Kantor Cabang Makassar terus berusaha mewujudkan transparansi dalam setiap pelayanan yang dilakukan kepada masyarakat, tidak terkecuali pada inovasi klaim elektronik. Klaim elektronik menjadi sarana bagi BPJS Ketenagakerjaan Kantor Cabang Makassar untuk membuktikan budaya keterbukaan yang dimiliki kepada masyarakat. Data di setiap akun peserta telah disajikan sesuai dengan jumlah dan keadaan yang sebenarnya, baik informasi gaji yang dilaporkan ke pihak BPJS Ketenagakerjaan, maupun status bayar iuran yang dilakukan oleh perusahaan atau pribadi peserta. Hal ini semakin mendorong BPJS Ketenagakerjaan untuk memiliki pengendalian internal agar tidak melakukan penyalahgunaan terhadap dana peserta.

Selain itu, tujuan adanya klaim elektronik adalah untuk mencegah terjadinya maladministrasi dalam setiap pelayanan yang diberikan, salah satunya dalam hal gratifikasi mempercepat pelayanan klaim. Lamanya waktu tunggu membuat masyarakat terkadang memanfaatkan calo untuk mempercepat proses antrean dan klaim. Tetapi dengan adanya Klaim elektronik, segala proses dilakukan secara cepat dan nomor antrean sudah ditentukan sehingga waktu yang digunakan dapat lebih efisien. Hal ini sekaligus menutup peluang bagi praktik percaloan atau sogok-menyogok antara peserta klaim dengan orang yang bekerja di BPJS Ketenagakerjaan Kantor Cabang Makassar. Klaim elektronik juga merupakan jawaban atas permasalahan ketidaksetaraan yang menjadi tantangan yang cukup besar dalam pelayanan publik. Hal ini karena beberapa keluhan masyarakat lebih pada sistem antrean yang kadang memprioritaskan orang orang tertentu. Dengan diterapkannya layanan klaim elektronik ini, termasuk di dalamnya sistem antrean yang telah terurut dan terjadwal, pelayanan kepada peserta klaim diharapkan dapat berjalan lebih baik. Prinsipnya adalah peserta yang cepat mendaftar dan datang sesuai jadwal, dialah yang diprioritaskan untuk dilayani.

\section{Lembaga yang Akuntabel}

Hasil penelitian menunjukkan bahwa BPJS Ketenagakerjaan Kantor Cabang Makassar terus berusaha mewujudkan akuntabilitas dalam setiap pelayanan yang dilakukan kepada masyarakat, tidak terkecuali pada inovasi klaim elektronik. Bagi BPJS Ketenagakerjaan Kantor Cabang Makassar, menjadi organisasi yang akuntabel merupakan misi yang akan terus dijalankan demi tercapainya tujuan sebagai penyelenggara jaminan sosial yang amanah. Sebagai organisasi pelayan publik, akuntabilitas BPJS Ketenagakerjaan Kantor Cabang Makassar harus dipertahankan agar tetap mendapatkan kepercayaan dari masyarakat.

3. Kreativitas Pemerintah Dalam Mencari Saran Dan Umpan Balik Dari Masyarakat.

Hasil penelitian menunjukkan bahwa BPJS Ketenagakerjaan Kantor Cabang Makassar terus berusaha mewujudkan kreativitas dalam setiap pelayanan yang diberikan kepada masyarakat, khususnya pada inovasi Klaim elektronik. Dalam 
penerapan Klaim elektronik, BPJS Ketenagakerjaan Kantor Cabang Makassar terus melakukan evaluasi untuk memperbaiki kualitas pelayanan. Penerapan Klaim elektronik merupakan komitmen BPJS Ketenagakerjaan dalam memberikan pelayanan berbasis partisipasi masyarakat. Salah satu cara yang ditempuh adalah dengan mencari saran dan umpan balik dari masyarakat terkait layanan klaim elektronik.

Ada berbagai bentuk kreativitas BPJS Ketenagakerjaan Kantor Cabang Makassar dalam mencari saran serta umpan balik dari masyarakat. Penilaian tersebut dapat dilihat melalui E-Survey di meja Customer Service Officer (CSO), kotak saran di samping pintu keluar, dan layanan pelaporan online seperti lapor.go.id dan whistle blowing system. Di samping itu, keterlibatan masyarakat dalam aktivitas pelayanan, khususnya inovasi klaim elektronik juga dapat dilihat dari umpan balik yang diketahui melalui petugas CSO dan security saat briefing singkat setiap sore, komentar-komentar pada Google Maps BPJS Ketenagakerjaan Kantor Cabang Makassar, atau layanan call center 0411-441581.

Berdasarkan pemaparan ketiga sub-indikator fokus tematik inovasi administrasi publik di atas, dapat dilihat bahwa BPJS Ketenagakerjaan Kantor Cabang Makassar telah menerapkan kunci Sustainability Development Goals (SDGs) pada United Nations Public Service Award (2017), yaitu Transparent, accountable and participatory institutions are the backbone of a people-centred public service.

\section{Mengatasi Masalah dengan Teknologi}

Hasil penelitian menunjukkan bahwa BPJS Ketenagakerjaan Kantor Cabang Makassar telah berusaha menerapkan inovasi layanan klaim elektronik dengan baik. Tetapi dalam pelaksanaannya masih memiliki beberapa tantangan dan kendala, terkhusus pada bagian pemanfaatan teknologi. Teknologi digunakan sebagai sarana yang efektif pengembangan kapasitas dan keterampilan secara bersamaan dalam mendukung pelaksanaan inovasi. Teknologi pun dinilai dapat menjadi penghubung elemen-elemen pelayanan publik yang terpisah ruang dan jarak secara efisien. Di samping itu, teknologi diharapkan dapat memainkan peran penting dalam meminimalisir penyalahgunaan kewenangan melalui transparansi data serta masalah lainnya.

\section{Kebijakan Penggunaan Teknologi}

Hasil penelitian menunjukkan bahwa BPJS Ketenagakerjaan Kantor Cabang Makassar telah berupaya untuk memaksimalkan pelayanan kepada masyarakat, khususnya pada masalah antrean yang panjang setiap hari dalam bentuk inovasi layanan klaim elektronik.

BPJS Ketenagakerjaan Kantor Cabang Makassar mengupayakan penggabungan antara kebijakan dengan pemanfaatan teknologi demi terciptanya pelayanan prima kepada masyarakat. Inovasi tersebut dapat terlaksana dengan baik jika didukung oleh ketersediaan pengelolaan data peserta jaminan sosial ketenagakerjaan. Salah satu langkah yang ditempuh oleh BPJS Ketenagakerjaan 
adalah mewajibkan peserta untuk mencantumkan Nomor Induk Kependudukan (NIK) pada setiap pendaftaran. Setelah itu, data tersebut akan dicocokkan dengan data pada adminduk dan akan dilanjutkan untuk diproses dalam sistem jika data telah sesuai.

Dari penjelasan tersebut, dapat diketahui bahwa BPJS Ketenagakerjaan Kantor Cabang Makassar terus berupaya mengumpulkan dan menyortir data dengan melakukan pemadanan data yang diintegrasikan dengan data adminduk sehingga peserta terdaftar dengan NIK yang valid sehingga verifikasi lebih mudah dilakukan. Dari data yang berhasil dikumpulkan oleh peneliti, dilihat bahwa pada tahun 2018 persentase jumlah NIK peserta valid, baik NIK peserta aktiv valid dan NIK peserta nonaktif valid masing-masing di atas $80 \%$ dan $70 \%$. Hal ini menunjukkan bahwa sebagian besar data NIK peserta yang terdaftar dinyatakan valid sehingga semakin valid data yang diperoleh maka semakin besar kepercayaan masyarakat terhadap kinerja BPJS Ketenagakerjaan Kantor Cabang Makassar, khususnya kepercayaan menggunakan inovasi layanan Klaim elektronik.

\section{Analisis Data Bantuan Teknologi}

Analisis data dengan menggunakan teknologi memliki peranan yang sangat besar dalam meningkatkan kualitas pelayanan publik. BPJS Ketenagakerjaan telah berupaya untuk menerapkan analisis data melalui penggunaan teknologi. Namun dalam pelaksanaanya, masih terdapat beberapa kendala akibat sistem aplikasi yang masih terbatas dan masih dalam tahap pengembangan.

Hasil penelitian menunjukkan bahwa mekanisme analisis data dalam layanan inovasi klaim elektronik masih berstatus semi-manual. Hal ini disebabkan oleh sejumlah berkas yang belum tergeneralisasi untuk diverifikasi, antara lain pengalaman kerja yang dikeluarkan oleh pihak perusahaan, data kependudukan yang dikeluarkan oleh Disdukcapil, lalu data kepesertaan yang dikeluarkan oleh BPJS Ketenagakerjaan, dan sarana transfer dana JHT dikeluarkan oleh pihak bank. Sampai saat ini komponen tersebut masih diperiksa secara manual sehingga integrasi data secara digital belum dapat diterapkan menyeluruh. Dengan demikian, pelayanan yang diberikan di BPJS Ketenagakerjaan Kantor Cabang Makassar pun masih kurang maksimal dalam hal efisiensi waktu pelayanan.

\section{Aksebilitas yang Besar}

Salah satu kriteria pelayanan publik adalah kemudahan akses layanan tersebut oleh seluruh kalangan masyarakat. Di samping itu, suatu layanan publik juga harus mudah digunakan (user friendly), mudah dimengerti, dan tidak membutuhkan waktu yang lama untuk beradaptasi dengan penggunaannya.

Pihak BPJS Ketenagakerjaan Kantor Cabang Makassar mengemukakan bahwa antrean Klaim elektronik didesain untuk tidak sulit digunakan. Alasannya adalah semua orang sudah familiar dengan aplikasi yang ada di gawainya masing-masing dan aplikasi BPJSTKU sebagai support service dari klaim elektronik 
sudah mendukung itu. Bahkan penggunaan klaim elektronik dikatakan lebih mudah daripada membuat akun media sosial seperti facebook. Apalagi selain dapat diakses melalui gawai, pengajuan klaim elektronik juga dapat dilakukan melalui website.

Hal tersebut sejalan dengan pengakuan sebagian besar peserta klaim yang ditemui oleh peneliti. Mereka mengakui bahwa layanan klaim elektronik tersebut dapat mereka akses dengan mudah karena sudah terbiasa dengan penggunaan teknologi seperti smartphone. Namun di balik pengakuan tersebut, tetap saja masih ada peserta yang merasa lebih nyaman ketika langsung datang ke Kantor BPJS Ketenagakerjaan karena dapat melakukan konfirmasi langsung jika menemukan kendala pengajuan klaim.

\section{Perhatian Terhadap Ancaman Keamanan dan Privasi}

Pemanfaatan teknologi dan jaringan internet dilakukan untuk meningkatkan kualitas pelayanan publik. Tetapi kesiapan suatu lembaga pelayanan publik untuk mendigitalisasi data dan prosesnya harus berbanding lurus dengan kesiapan untuk menghadapi risiko digitalisasi tersebut. Risiko yang dimaksud adalah munculnya ancaman terhadap keamanan dan privasi data peserta BPJS Ketenagakerjaan. Pimpinan BPJS Ketenagakerjaan Kantor Cabang Makassar mengemukakan bahwa NIK dan nomor kartu peserta harus dirahasiakan untuk menghindari penyalahgunaan data, terutama jumlah saldo yang dimiliki oleh seorang tenaga kerja meskipun klaim tidak dapat dilakukan.

Hal tersebut menjadi gambaran bahwa di balik kemudahan akses klaim elektronik terdapat celah bagi orang yang tidak bertanggungjawab untuk melakukan penyalahgunaan informasi. Data-data terkait tenaga harus dilindungi dengan baik.

Berdasarkan pemaparan empat sub-indikator di atas, dapat disimpulkan bahwa meskipun inovasi layanan Klaim elektronik telah diterapkan namun tetap saja memunculkan masalah-masalah yang menghambat penerapannya.

\section{Kebijakan yang Koheren dan Terintegrasi}

Kebijakan yang koheren dan terintegrasi dapat terwujud ketika komunikasi, interaksi, dan koordinasi aktor-aktor dalam sektor publik dengan aktor non pemerintah berjalan dengan baik. Terkait kebijakan layanan publik, BPJS Ketenagakerjaan Kantor Cabang Makassar memerlukan kebijakan yang kompleks dan terhubung antara kebijakan satu dengan kebijakan yang lain. Dalam penelitian ini kebijakan yang koheren dan terintegrasi dapat dilihat dari dua aspek, yakni kesatuan dan kepaduan pemahaman mengenai kebijakan serta partisipasi aktor lain untuk mendukung pelaksanaan kebijakan di BPJS Ketenagakerjaan, terkhusus di Kantor Cabang Makassar.

1. Koherasi Kebijakan 
Suatu inovasi tentu membutuhkan koherensi kebijakan sehingga dalam pelaksanaannya, dalam hal ini klaim elektronik mendapat dukungan dari seluruh elemen yang memiliki kesatuan dan kepaduan tujuan. BPJS Ketenagakerjaan memiliki Standar Operasional Prosedur (SOP) pada setiap layanan yang ditawarkan. Namun SOP tersebut berlaku secara nasional dan umum dan tidak dapat direvisi oleh kantor cabang. Regulasi tidak dapat dibuat di kantor cabang, semua aturan tersentralisasi di pusat, baik itu regulasi terkait undang-undang, peraturan pemerintah, maupun peraturan direksi. Hal ini membuat beberapa kantor cabang kesulitan saat menghadapi kendala yang ditemui di kantor masingmasing, tidak terkecuali BPJS Ketenagakerjaan Kantor Cabang Makassar.

Hasil penelitian menunjukkan bahwa BPJS Ketenagakerjaan Kantor Cabang Makassar tidak memiliki wewenang untuk menentukan sendiri solusi terkait masalah yang ditemukan sehari-hari yang berkaitan dengan SOP. SOP Klaim elektronik berasal dari BPJS Ketenagakerjaan Pusat sehingga kantor cabang tidak bisa membuat aturan sendiri sesuai keadaan setempat yang dihadapi.

Berdasarkan penjelasan tersebut, dapat disimpulkan bahwa berjalannya inovasi layanan Klaim elektronik belum mendapat dukungan penuh dari penentu kebijakan. Padahal keterbatasan jumlah pegawai inilah yang menjadi salah satu faktor penghambat pelayanan publik. Masalah ini diharapkan mendapatkan perhatian lebih sehingga menjadi bahan pertimbangan bagi pimpinan selaku penentu kebijakan di BPJS Ketenagakerjaan, baik pada tataran kantor cabang maupun kantor pusat.

\section{Dukungan Aktor Publik}

Salah satu kunci keberhasilan pelaksaaan kebijakan di tataran lembaga pelayanan publik adalah komunikasi dan koordinasi yang baik. Komunikasi dan koordinasi yang dimaksud adalah komunikasi secara menyeluruh, baik antarpihak internal maupun koordinasi dengan aktor lain yang terkait dengan pelaksanaan suatu layanan inovasi. Hasil penelitian menunjukkan bahwa interaksi dan komunikasi pada pelaksanaan inovasi Klaim elektronik menjadi tanggung jawab pemimpin, dalam hal ini Kepala BPJS Ketenagakerjaan Kantor Cabang Makassar. Meskipun masih memiliki kendala pada data kepesertaan, pihak BPJS Ketenagakerjaan Kantor Cabang Makassar berharap dapat memiliki sistem yang lebih terintegrasi baik dengan perusahaan sehingga proses verifikasi juga dapat dilakukan oleh perusahaan karena keaslian data peserta telah terjamin.

Berdasarkan penjelasan tersebut, dapat diketahui bahwa pimpinan BPJS Ketenagakerjaan Kantor Cabang Makassar memiliki upaya untuk meningkatkan kualitas pelayanan Klaim elektronik dengan merencanakan agar inovasi ini bisa berjalan dan berkembang lebih baik. BPJS Ketenagakerjaan melibatkan aktor pemerintah dalam kegiatan operasionalnya. Fokus Klaim elektronik yang lebih banyak kepada pelayanan klaim JHT membuat BPJS Ketenagakerjaan membangun kemitraan dengan instansi/perusahaan yang menaungi pekerja yang 
melakukan klaim tersebut, baik tenaga honorer pemerintah, maupun karyawan BUMN/BUMS.

Berdasarkan penjelasan tersebut diketahui bahwa salah satu fungsi dari membangun hubungan dengan instansi yang menaungi tenaga kerja adalah koordinasi dalam bidang pelayanan. Hal tersebut juga dijalankan oleh BPJS Ketenagakerjaan Kantor Cabang Makassar yang membangun komunikasi baik dengan Dinas Tenaga Kerja Provinsi Sulawesi Selatan, Dukungan yang sama juga didapatkan dari Gubernur Sulawesi Selatan yang mendukung dengan mengesahkan Peraturan Gubernur Sulawesi Selatan No. 135 tentang Jaminan Sosial Ketenagakerjaan. Sedangkan terkait koordinasi dengan pihak swasta, BPJS Ketenagakerjaan membentuk Forum HRD sebagai ruang untuk menyelurkan aspirasi perusahan.

Hasil penjabaran dua sub-indikator tersebut menunjukkan bahwa BPJS Ketenagakerjaan Kantor Cabang Makassar telah berupaya membangun koneksi dan relasi kepada berbagai pihak untuk merealisasikan tujuan layanan penerapan inovasi Klaim elektronik sesuai harapan. Namun hasil dari upaya tersebut ternyata belum mampu memenuhi kriteria yang diinginkan dalam fokus tematik inovasi administrasi publik sebagai kunci Sustainability Development Goals (SDGs).

\section{Kesimpulan}

Berdasarkan hasil analisis berdasarkan kriteria Inovasi model UNPSA (2017) maka dapat disimpulkan bahwa pelaksanaan inovasi klaim elektronik Jaminan Hari Tua di BPJS Ketenagakerjaan Kantor Cabang Makassar dapat dijelaskan oleh indikator yang sesuai dengan kriteria United Nations Public Service Award (2017). Adapun indikatornya yaitu; pertama, kepemimpinan dan kapasitas pemerintah yang inovatif, dalam hal ini BPJS Ketenagakerjaan telah menerapkan kepemimpinan yang visioner sehingga memberi ruang untuk terus berinovasi dan menerapkan kolaborasi dengan pihak pemerintah dalam hal ini Dinas Tenaga Kerja dan Transmigrasi Provinsi Sulawesi Selatan, perusahaan binaan, bank BNI, bank BTN dan asosiasi pengusaha. Kedua, Lembaga yang Transparan, Akuntabel, dan Partisipastif, dalam hal ini penerapan klaim elektronik memberikan transparansi pengelolaan dana jaminan hari tua melalui aplikasi yang dapat diakses oleh semua peserta. Adanya pengawsan dari pihak Satuan Pengawas Internal, Kantor Akuntan Publik, Otoritas Jasa Keuangan untuk menjaga agar proses organisasi dan pengelolaan seluruh dana jaminan berjalan sesuai dengan aturan yang berlaku. Adanya survey internal oleh BPJS Ketenagakerjaan Kantor Cabang Makassar yang ditujukan lansung kepada peserta dan adanya kunjungan dari ombudsman untuk mengawasi kualitas pelayanan. Ketiga, mengatasi masalah dengan teknologi, dalam hal ini dilakukan digitalisasi data dengan menggunakan NIK sebagai sumber data yang paling utama, dibarengi dengan pemanfaatan teknologi yang user friendly. Namun penerapan klaim elektronik belum optimal karena masih membutuhkan keterlibatan pegawai dalam proses verifikasi. Keempat, kebijakan yang koheren dan terintegrasi, dalam hal ini BPJS 
Ketenagakerjaan Kantor Cabang Makassar mendapat dukungan dari Dinas Tenaga Kerja dan Transmigrasi, namundisisi internal BPJS Ketenagakerjaan masih terkendala dengan penambahan pegawai yang merupakan kebijakan di kantor pusat.

\section{Persantunan}

Terima kasih yang tak terhingga penulis ucapkan kepada: Bapak Dr. M. Tahir Haning, M.Si. dan Dr. Syahribulan, M.Si. selaku pembimbing yang telah memberikan arahan dan masukan selama proses penyusunan jurnal ini. Bapak Prof. Deddy T. Tikson, Ph.D. dan Dr. Suryadi Lambali, M.Si yang telah memberikan arahan dan masukan dalam menyempurnakan jurnal ini. Prof. Akmal Ibrahim, M.Si, selaku Ketua Program Pascasarjana Studi Administrasi Publik.

\section{Daftar Pustaka}

Bessan. 2009. Innovation London, New York, Munich, Melbourne and Delhi.

Borins, S. (2001). The challenge of innovating in government. Arlington: The Pricewaterhouse Coopers Endowment for The Business of Government.

Permenaker No 46/2015 tentang jaminan Hati Tua (JHT)

Prasojo, Eko dan Teguh Kurniawan. 2006. Bebas Iuran Sekolah dan JK : Inovasi Pro Masyarakat Miskin di Kabupaten Jembrana. Jurnal PSPK, Edisi VIII. Hal. 100113.

Siagian, S.P. (1992). Organisasi Kepemimpinan \& Perilaku Administrasi. Jakarta, Rineka Cipta.

Suwondo, 2001, “Desentralisasi Pelayanan Publik: Hubungan Komplementer antara sector Negara, Mekanisme Pasar dan Organisasi Non Pemerintah". Jurnal Administrasi Negara (Vol. 1 No. 2 Maret 2001) Malang : FIA Unibraw.

Tim UNPAS. (2017). Panduan Penulisan Karya Tulis Ilmiah (KTI). Bandung: Tidak Diterbitkan.

UNDESA. 2006. Innovations in Governance and Public Administration: Replicating What Works. New York : United Nations Publication

UNDESA. 2017. The Future is Now, Accelerating Public Service Innovation for Agenda 2030. New York: United Nations Publication 